\title{
Structural analysis of reinforced asphalt pavement by impregnated surface geotextile
}

\author{
Análise estrutural de pavimentos asfálticos reforçados por geotêxtil \\ superficialmente impregnado
}

\author{
Juliana de Paula Rezende ${ }^{1}$, Heraldo Nunes Pitanga ${ }^{2}$, Taciano Oliveira da Silva ${ }^{3}$, \\ Geraldo Luciano de Oliveira Marques ${ }^{4}$, Géssica Soares Pereira ${ }^{5}$ \\ ${ }^{1}$ Universidade Federal de Viçosa, Minas Gerais - Brasil, juliana.rezende@ufv.br \\ 2Universidade Federal de Viçosa, Minas Gerais - Brasil, heraldo.pitanga@ufv.br \\ 3Universidade Federal de Viçosa, Minas Gerais - Brasil, taciano.silva@ufv.br \\ ${ }^{4}$ Universidade Federal de Juiz de Fora, Minas Gerais - Brasil, geraldo.marques@ufjf.edu.br \\ 5Universidade Federal de Viçosa, Minas Gerais - Brasil, gessica.soares@ufv.br
}

\section{Recebido:}

16 de outubro de 2019

Aceito para publicação:

16 de março de 2020

Publicado:

15 de dezembro de 2020

Editor de área:

Jorge Barbosa Soares

\section{Keywords:}

Composite hot asphalt mixtures.

Geosynthetic reinforcement.

Geotextile.

Surface impregnation.

Structural analysis.

\section{Palavras-chaves:}

Misturas asfálticas a quente

compostas.

Reforço geossintético.

Geotêxtil.

Impregnação superficial.

Análise estrutural.

DOI:10.14295/transportes.v28i5.2203

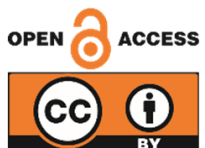

\begin{abstract}
The present research contemplated the mechanistic-empirical analysis of unreinforced and reinforced asphalt pavements by impregnated surface geotextile. The mechanical properties determined in the laboratory derive from the tensile strength by diametral compression (TS), resilient modulus (RM) and fatigue life (Nf) tests. Insertion of the reinforcement into the asphalt mixture provided TS and RM increments, as well as reducing the risk of fatigue cracking. In the structural analyzes, horizontal tensile stresses and vertical compression stresses at the lower edge of the binder course were verified. The analysis based on the statically determined mechanical strength parameter (TS) showed a structural superiority of the unreinforced system compared to the geotextile reinforced system, in contrast to the analysis based on the dynamically determined structural response parameter (Nf). It is assumed that, because it does not translate the mobilized strength by asphalt concrete under dynamic loading condition, the structural safety analysis based on static properties masks the improvements generated by the geosynthetic reinforcement.
\end{abstract}

\section{RESUMO}

A presente pesquisa contemplou a análise mecanístico-empírica de pavimentos asfálticos não reforçado e reforçado por geotêxtil superficialmente impregnado. As propriedades mecânicas determinadas em laboratório derivam dos ensaios de resistência à tração por compressão diametral (RT), módulo de resiliência (MR) e vida de fadiga (Nf). A inserção do reforço à mistura asfáltica conferiu incrementos de RT e MR, além de reduzir o risco de ruptura por fadiga. Nas análises estruturais, foram verificadas as tensões horizontais de tração e verticais de compressão no bordo inferior da camada de ligação. A análise baseada no parâmetro de resistência mecânica estaticamente determinada (RT) evidenciou uma superioridade estrutural do sistema não reforçado comparativamente ao reforçado por geotêxtil, contrariamente à análise baseada no parâmetro de resposta estrutural dinamicamente determinada (Nf). Supõe-se que, por não traduzir a resistência mobilizada pelo concreto asfáltico sob condição de carregamento dinâmico, a análise de segurança estrutural baseada em propriedades estáticas encobre as melhorias geradas pelo reforço geossintético.

\section{INTRODUCTION}

In the field of road engineering, as regards asphalt pavements, the repetition of tensile stresses at the lower edge of the surface course as a result of repeated passage of vehicles on their 
surface results in the development of microcracking, evolving into cracking and ultimately larger failures in asphalt concrete.

The construction industry has sought to promote development and stimulate the use of geosynthetics for reinforcement of new and repaired asphalt pavements, in order to mitigate the deleterious effects of increasing loading repetitions due to traffic, especially heavy vehicles, which are responsible for the pathological mechanism of fatigue cracking (Brown et al., 2001; Virgili et al., 2009).

The introduction of interlayer of geosynthetic reinforcement into a pavement system promotes the absorption of mobilized tensile strains during loading. When placed on the asphalt layers, these interlayers efficiently absorb tensile stresses and reduce vertical strain, thus retarding the cracking propagation (Khodaii et al., 2009; Li et al., 2016).

At the laboratory scale, many authors have studied the performance of reinforced asphalt layers by inserting an interlayer of a geosynthetic element. Prieto et al. (2007) developed a laboratory test by simulating the main mechanisms and factors of distress in pavement. This study evaluated the mechanical behavior of unreinforced and reinforced surface course by fiberglass geotextiles, concluding that the best results were obtained with the insertion of geotextiles providing tensile strength high to the system.

Zamora-Barraza et al. (2011) studied the increase in durability of surface course provided by the inclusion of geosynthetics. These authors also compared the behavior of different antireflective cracking systems using dynamic tests. Overall, the insertion of geosynthetics into asphalt layers retard cracking propagation, ensuring better performance and greater resistance to deformations. Vismara et al. (2012) employed static and dynamic tests to determine the behavior of geotextiles acting as anti-reflective cracking system, concluding that the opening of cracking was reduced by approximately $20 \%$ with the installation of geosynthetics in asphalt layers.

However, research has found that the presence of geosynthetic interlayers in surface course may reduce the interface bond strength, resulting in the physical separation of the sublayers from this surface course (Zamora-Barraza et al., 2010; Saride and Kumar, 2017). The separation effect is more frequent for interlayer reinforcement that do not have adequate openings to facilitate contact mechanism through holes among asphalt layers. This makes it necessary, therefore, to apply impregnation asphalt binder (adherence coating) to improve the contact of the interface among the interlayers and the asphalt layers (Kumar and Saride, 2018).

In this context, Rezende et al. (2018) developed a study whose purpose was to evaluate the possible benefit of geotextile impregnation to the mechanical properties of reinforced asphalt mixtures. Four different scenarios were adopted: no impregnation, impregnated on both sides of the geotextile, impregnated on the upper side and impregnated on the bottom side. It was observed that the configuration corresponding to geotextile upper surface impregnation was the most efficient in relation to the others analyzed scenarios. However, it was experimentally found that all impregnation scenarios resulted in higher mechanical responses than those of unpregnated reinforced mixtures, confirming the importance of reinforcement impregnation in reinforced surface course by geotextile.

It is important to note that most stress, strains and displacements analysis methods for such reinforced pavements are based on empirical protocols derived from results of laboratory and field tests, which are limited to the experimental conditions from which they were developed 
(Tang et al., 2016). However, there is no widely accepted approach by the technical community to design reinforced asphalt pavements with geosynthetic.

The mechanistic-empirical (ME) approach for analysis and design of conventional pavements, i.e. without the inclusion of geosynthetics, has wide technical-scientific recognition due to its many advantages over the empirical approach, including a more reliable asphalt pavement performance prediction. In these analysis, stresses, strains and displacements are obtained at remarkable points of a multilayer structure (NCHRP, 2004; Alhasan et al., 2018).

To combine the proven technical advantages of using impregnated surface geotextiles as an surface course reinforcement with the equally advantageous and reliable mechanistic-empirical approach to asphalt pavements, the present research analyzed the structural responses of reinforced asphalt pavements by geotextile, considering the influence of this impregnation condition of reinforcement on surface course under traffic loading specific conditions using the Mechanistic-Empirical Pavement Analysis and Design Software (me-PADS) as an analysis tool.

The research included the investigation of reinforced surface course by geotextile impregnated on the upper side, as found by Rezende et al. (2018), as well as control surface course (unreinforced) which have also been analyzed for comparative purposes. In particular, horizontal tensile stresses and vertical compression stresses at the lower edge of the binder course were verified.

In this research, a protocol of verifications based on parameters derived from laboratory tests and structural analysis was proposed, allowing the assessment, for reinforced and unreinforced surface course, of the respective susceptibilities to the risk of cracking by static tensile and the risk of cracking by fatigue. Therefore, these verifications provide technical-scientific support to the designer for decision making regarding the choice of this geosynthetic material (impregnated surface geotextile) aiming at improving the structural performance of the asphalt mixture.

\section{MATERIALS AND METHODS}

\subsection{Materials}

The mineral coarse aggregates (gravel 0 and 1) and fine (crusher dust) used in this research are gneissic. The asphalt binder employed was the CAP 50/70. The geosynthetic reinforcement material of the investigated asphalt mixtures corresponded to a nonwoven geotextile whose technological characteristics were provided by the manufacturer.

\subsection{Methods}

\subsubsection{Technological characterization of materials}

Table 1 presents the results regarding the technological characterization of mineral aggregates. Also included in this Table are the results for the technological characterization of asphalt binder, which are in compliance with material specification EM 095 (DNIT, 2006b). The technological characteristics of geotextile are presented in Table 1.

\subsubsection{Grading of design}

Design asphalt mixtures corresponding to two grading envelopes (B and C), specified by ES 031 (DNIT, 2006a), were used. Figure 1 presents the grading of design adopted in this research for them. For these envelopes, the design gradation curves were determined in accordance with the 
limits imposed by the mentioned service specification according to the Marshall mix design method based on the test method ME 043 (DNER, 1995).

Table 1 - Results of the characterization tests of mineral aggregates, asphalt binder and main technological characteristics of geosynthetic employed in this research

\begin{tabular}{|c|c|c|c|c|c|}
\hline \multicolumn{4}{|c|}{ Mineral aggregates } & \multicolumn{2}{|c|}{ Asphalt binder } \\
\hline Property & Gravel 0 & Gravel 1 & Crusher Dust & Property & CAP 50/70 \\
\hline $\begin{array}{l}\text { Los Angeles abrasion } \\
\text { (DNER ME 035/98) }\end{array}$ & 45 & 45 & - & $\begin{array}{l}\text { Penetration (dmm) } \\
\text { (DNIT ME 155/10) }\end{array}$ & 57 \\
\hline $\begin{array}{c}\text { Absorption (\%) } \\
\text { (DNER ME 195/97) }\end{array}$ & 1.14 & 1.14 & - & $\begin{array}{c}\text { Real specific density }\left(\mathrm{g} / \mathrm{cm}^{3}\right) \\
\text { (DNER ME 009/98) }\end{array}$ & 1.010 \\
\hline $\begin{array}{l}\text { Adhesivity to asphalt } \\
\text { binder } \\
\text { (DNER ME 078/94) }\end{array}$ & $\begin{array}{l}\text { Unsatisfactory } \\
\text { (1) }\end{array}$ & $\begin{array}{l}\text { Unsatisfactory } \\
\text { (1) }\end{array}$ & - & $\begin{array}{l}\text { Softening point }\left({ }^{\circ} \mathrm{C}\right) \\
\text { (DNIT ME } 131 / 10)\end{array}$ & 51 \\
\hline $\begin{array}{c}\text { Form index } \\
\text { (DNER ME 086/94) }\end{array}$ & 0.68 & 0.68 & - & $\begin{array}{c}\text { Relative Density } \\
\text { (DNER ME 009/98) }\end{array}$ & 1.006 \\
\hline 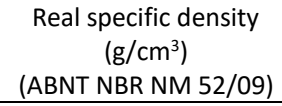 & 2.794 & 2.794 & 2.794 & $\begin{array}{l}\text { Points of flash }\left({ }^{\circ} \mathrm{C}\right) \\
\text { (DNER ME } 148 / 94)\end{array}$ & 343 \\
\hline $\begin{array}{c}\text { Soundness (\%) } \\
\text { (DNER ME 089/94) }\end{array}$ & 0.38 & 0.38 & - & $\begin{array}{l}\text { Points of fire }\left({ }^{\circ} \mathrm{C}\right) \\
\text { (DNER ME } 148 / 94)\end{array}$ & 365 \\
\hline $\begin{array}{l}\text { Sand equivalent (\%) } \\
\text { (DNER ME 054/97) }\end{array}$ & - & - & 59 & $\begin{array}{l}\text { Solubility in trichlorethylene } \\
\text { (\%) (ABNT NBR 14855/15) }\end{array}$ & 100 \\
\hline $\begin{array}{c}\text { Angularity } \\
\text { (ASTM C 1252/06) }\end{array}$ & - & - & $\begin{array}{c}\text { Sub Rounded } \\
\text { Class } \\
\end{array}$ & $\begin{array}{l}\text { Viscosity Saybolt-Furol } \\
\text { (DNER ME 004/94) }\end{array}$ & $\begin{array}{c}135^{\circ} \mathrm{C}-172 \text { seconds } \\
150^{\circ} \mathrm{C}-64 \text { seconds }\end{array}$ \\
\hline $\begin{array}{l}\text { Apparent specific } \\
\text { density }\left(\mathrm{g} / \mathrm{cm}^{3}\right) \\
\text { (ABNT NBR NM 52/09) }\end{array}$ & 2.705 & 2.705 & - & & \\
\hline $\begin{array}{c}\text { Elongated and flat } \\
\text { particles } \\
\text { (ASTM D 4791/10) }\end{array}$ & $\begin{array}{l}\text { Semi-Long- } \\
\text { Semicircular } \\
\text { Class }\end{array}$ & $\begin{array}{l}\text { Semi-Long- } \\
\text { Semicircular } \\
\text { Class }\end{array}$ & - & & \\
\hline \multicolumn{6}{|c|}{ (1): satisfactory with $0.1 \%$ by weight of asphalt binder of Betudope additive. } \\
\hline \multicolumn{6}{|c|}{ Geosynthetic } \\
\hline \multicolumn{2}{|c|}{ Property } & \multicolumn{2}{|r|}{ Unity } & & \\
\hline $\begin{array}{r}\text { Main Raw } \\
\text { Weig } \\
\text { Tensile st }\end{array}$ & aterial & \multicolumn{2}{|r|}{$\mathrm{g} / \mathrm{m}^{2}$} & & 150 \\
\hline $\begin{array}{r}\text { Longitu } \\
\text { Transv } \\
\text { Strain in tens }\end{array}$ & $\begin{array}{l}\text { nal } \\
\text { sal } \\
\text { strength }\end{array}$ & \multicolumn{2}{|r|}{$\mathrm{kN} / \mathrm{m}$} & & $\begin{array}{l}7 \\
8\end{array}$ \\
\hline $\begin{array}{r}\text { Longitu } \\
\text { Transv } \\
\text { Trapezoidal te }\end{array}$ & $\begin{array}{l}\text { nal } \\
\text { sal } \\
\text { strength }\end{array}$ & \multicolumn{2}{|r|}{$\%$} & \multicolumn{2}{|r|}{$>70$} \\
\hline Longitu & & \multirow{2}{*}{\multicolumn{2}{|c|}{$\mathrm{kN} / \mathrm{m}$}} & \multicolumn{2}{|r|}{220} \\
\hline Transv & & & & \multicolumn{2}{|r|}{200} \\
\hline
\end{tabular}

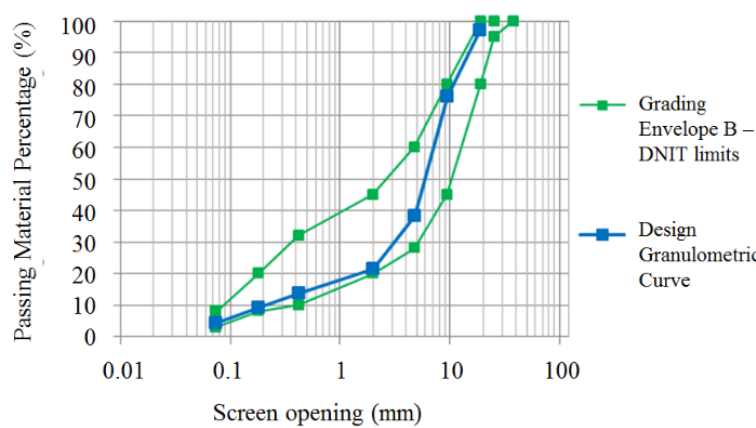

(a)

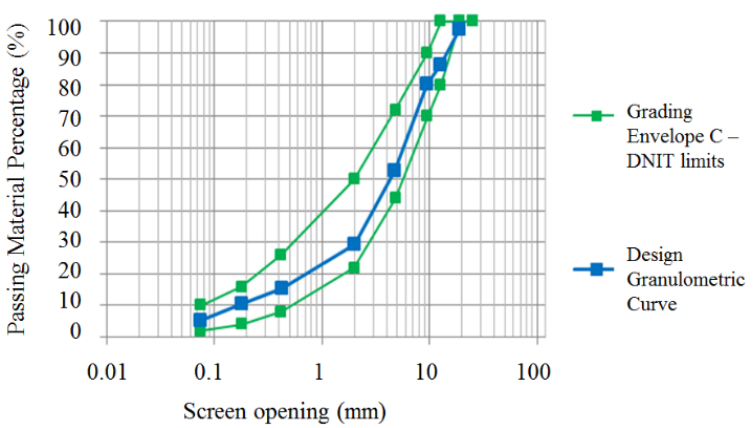

(b)

Figure 1. Grading of design for both grading envelopes of this research according to ES 031 (DNIT, 2006a): (a) Grading envelope B and (b) Grading envelope C 


\subsubsection{Design asphalt mixtures}

The asphalt binder design content corresponding to the grading envelopes $\mathrm{B}$ and $\mathrm{C}$ were determined on the basis of the VC (voids content) - VFB (voids filled with bitumen) criterion, according to the maximum and minimum limits for such parameters, defined by the service specification ES 031 (DNIT, 2006a). Asphalt binder design content of 4.2\% and 4.7\% were obtained for grading envelopes $\mathrm{B}$ and $\mathrm{C}$, respectively.

\subsubsection{Molding of test specimens}

For making test specimens of reinforced and unreinforced composite surface course, the component materials of the design asphalt mixtures were heated in a drying oven, the asphalt binder at $165^{\circ} \mathrm{C}$ and the aggregates at $175^{\circ} \mathrm{C}$. After proper heating of these materials, they were homogenized and placed into compaction molds. First, the design asphalt mixture corresponding to the grading envelope B was deposited, which is equivalent to the binder course, followed by the insertion of the impregnated geotextile and, finally, the design asphalt mixture of the grading envelope $\mathrm{C}$, equivalent to the wearing course.

Subsequently, the composite asphalt mixture was subjected to the compaction procedure, which was performed at $140{ }^{\circ} \mathrm{C}$ to ensure that the CAP $50 / 70$ had the viscosity determined by service specification ES 031 (DNIT, 2006a). After the compaction procedure was completed, the set was cooled to room temperature on a flat surface for 24 hours for subsequent extraction of the specimen from the reinforced composite asphalt mixture.

For impregnation of the geotextile, the CAP 50/70 was used, and the impregnation content of $0.36 \mathrm{~L} / \mathrm{m}^{2}$ for the tack coat was adopted, as recommended by the service specification ES 145 (DNIT, 2012). According to Rezende et al. (2018), geotextile impregnated on the upper side was chosen because it represents the best impregnation configuration analyzed for the geotextile, ensuring an adequate mechanical response, as well as a satisfactory adherence on the interface between the reinforcement and the asphalt mixture.

For unreinforced composite asphalt mixtures, a procedure similar to that described above was adopted, except, of course, for the insertion of impregnated geotextile.

\subsubsection{Mechanical tests}

For the composite asphalt mixtures analyzed (with and without reinforcement), mechanical properties of interest were determined, with a view to further analysis of their effects on the structural performance of investigated asphalt pavements. The following mechanical laboratory tests were performed according to the respective normative requirements:

- Resilient modulus - ME 135 (DNIT, 2018a);

- Tensile strength by diametral compression - ME 136 (DNIT, 2018b);

- Fatigue life - ME 183 (DNIT, 2018c).

For the resilient modulus (RM) and tensile strength by diametral compression (TS) tests, for each reinforcement condition of composite surface course (reinforced and unreinforced), 3 specimens were molded. For the fatigue life test, for these same reinforcement conditions, 6 specimens were molded. The loading employed in this test corresponded to $15 \%, 20 \%, 25 \%$, $30 \%, 35 \%$ and $40 \%$ of the TS's of reinforced and unreinforced composite asphalt mixtures.

From the fit of the mathematical model corresponding to Equation 1 (DNIT, 2018c) to the experimental data of fatigue life tests, were obtained representative equations of the fatigue 
response of each analyzed asphalt mixture (reinforced and unreinforced), which were later used to calculate the " $\mathrm{N} f$ " number of load repetitions required for the adopted asphalt pavement to suffer fatigue failure, considering the critical stresses provided by structural analysis.

considering:

$$
\mathrm{N}_{\mathrm{f}}=\mathrm{k}_{1}(1 / \Delta \sigma)^{\mathrm{k} 2}
$$

$\mathrm{N}_{\mathrm{f}}$ : number of load repetitions required to cracking the specimen;

$\mathrm{k}_{1} \mathrm{e} \mathrm{k}_{2}$ : experimental parameters;

$\Delta \sigma: \quad$ algebraic difference between horizontal tensile stress and vertical compression stress in the center of the specimen.

\subsubsection{Structural analysis of asphalt pavement}

Three loading and tire pressure levels were considered in the structural analysis of the asphalt pavement. An asphalt pavement consisting of a composite surface course (wearing course and binder course at the same time), which could be reinforced or unreinforced, base course and subgrade reinforcement, all seated on the subgrade, was adopted for purposes of structural analysis.

The structural analysis was performed using the me-PADS software, which combines a computational stress-strain mechanism with models of paving materials developed at CSIR Transportek. This mechanistic-empirical analysis of stresses and strains in pavements takes into account the linear elastic behavior of the component materials of the layers for a three-dimensional system and the calculation is performed by the finite element method.

The input data entered in the software for the structural analysis were those related to the properties of structural layers (thickness, modulus of elasticity and Poisson ratio), location and magnitude of loads and coordinates of the points for determining the structural responses of the adopted asphalt pavement.

Therefore, for the verification of horizontal tensile stresses and vertical compression stresses at the lower edge of the binder course, analysis points were considered on the vertical axis under symmetry between the wheels. The points analyzed for each scenario were: 1 and 3 - vertical axis under the wheels (abscissa $X=0 \mathrm{~mm} ; \mathrm{X}=300 \mathrm{~mm}$ ) and 2 - vertical axis of symmetry between the wheels (abscissa $\mathrm{X}=150 \mathrm{~mm}$ ).

In order to perform a linear elastic analysis of the adopted asphalt pavement, the resilient modulus (RM) was considered equal to the modulus of elasticity (E) for input data for structural layers. According to Ponte et al. (2014), when it is impossible to determine the Poisson ratio (v), it is recommended to use the value of $v=0.30$, being kept constant for asphalt layers and granular (base course) in all analyzes performed.

Regarding the characteristics of the materials used in the adopted asphalt pavement layers, data from Carmo's study (1998) were extracted for the subgrade and the subgrade reinforcement layer. Regarding the base course, the parameters of Ponte et al. (2014) served as the basis.

The loading levels considered in this research were as follows:

- L1 equal to $80 \mathrm{kN}$ (8.2 tf): load corresponding to 18,000 lb standard axle;

- L2 equal to $98 \mathrm{kN}$ (10.0 tf): maximum load allowed by Brazilian law for dual wheel single-axle (DWSA); 
- L3 equal to $118 \mathrm{kN}$ (12.0 tf): load 20\% above the maximum allowed by Brazilian law, $10 \%$ being the legal tolerance limit.

Three tire pressure levels were used:

- P1 equal to $563 \mathrm{kPa}$ (80 psi): standard pressure used on the AASHTO experimental track and standardized for the determination of deflection;

- P2 equal to $633 \mathrm{kPa}$ (90 psi): pressure representative of an average value;

- P3 equal to $703 \mathrm{kPa}$ (100 psi): pressure representing a high value.

Figure 2 illustrates the adopted asphalt pavement employed in the structural analysis provided for in this research.

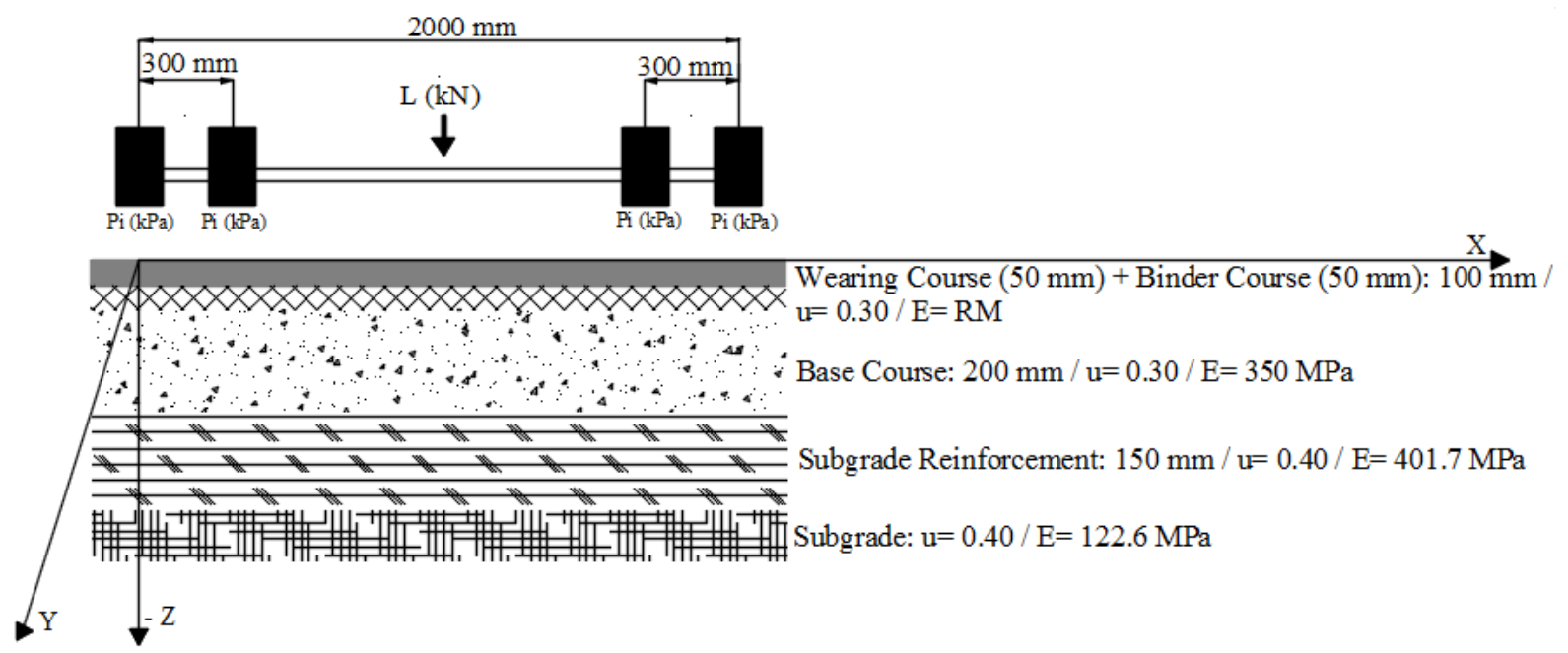

Figure 2. Scheme of the cross section of asphalt pavement adopted in structural analysis.

\section{RESULTS AND DISCUSSIONS}

\subsection{Mechanical tests}

Figures $3 \mathrm{a}$ and $3 \mathrm{~b}$ shows the average values of TS and RM, respectively, determined for specimens of composite asphalt mixtures tested with and without insertion of the reinforcement element (impregnated surface geotextile).

The results from the fatigue life test are presented in Figure 3c, which describe fatigue life through the relationship between the number of load repetitions to failure $\left(\mathrm{N}_{\mathrm{f}}\right)$ versus stresses difference $(\Delta \sigma)$. The mathematical equations obtained by linear regression for these curves are also presented.

The increase in TS obtained in this research for reinforced systems (Figure 3a) is estimated to be associated not only with the presence of reinforcement, but also with better mobilization of their bearing capacity or stress absorption, due to impregnation of the geotextile's surface and, consequently, of an adequate geosynthetic's adherence/contact with the asphalt layers of surface course (binder course and wearing course). The superior structural response of the reinforced system, translated by the TS values, corroborates the experimental findings of Caltabiano and Brunton (1991) and Zamora-Barraza et al. (2011), whose research showed a greater gain in interface shear strength (greater adherence) between asphalt layers in contact with impregnated geotextiles, showing the contribution of this impregnation in structural behavior. 
In this context, research developed by Caltabiano and Brunton (1991), Brown et al. (2001), Zamora-Barraza et al. (2010) and Sudarsanan et al. (2018) showed that interlayers without openings (geotextiles) are less resistant to shear at the interface with the asphalt layer, which causes adverse pavement mechanical responses. However, this deficiency can be suppressed by impregnation treatments at the interface that guarantee better adherence between reinforcement and asphalt layers (Aldea and Darling, 2004; Ferrotti et al., 2012).

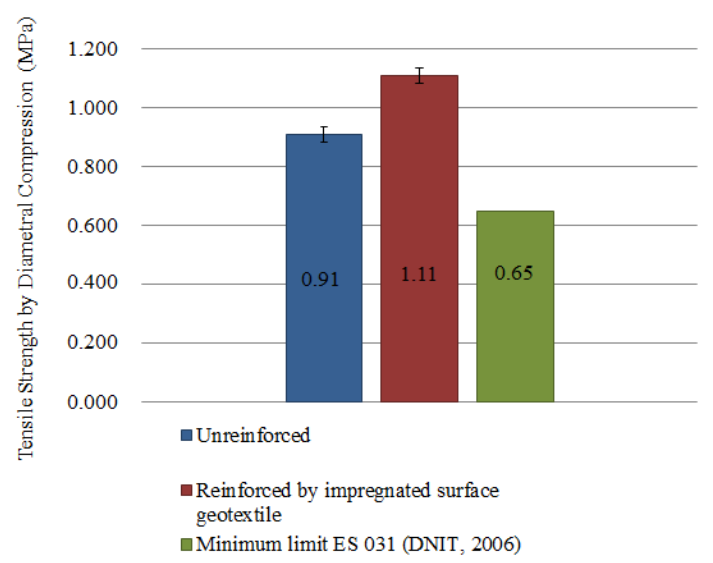

(a)

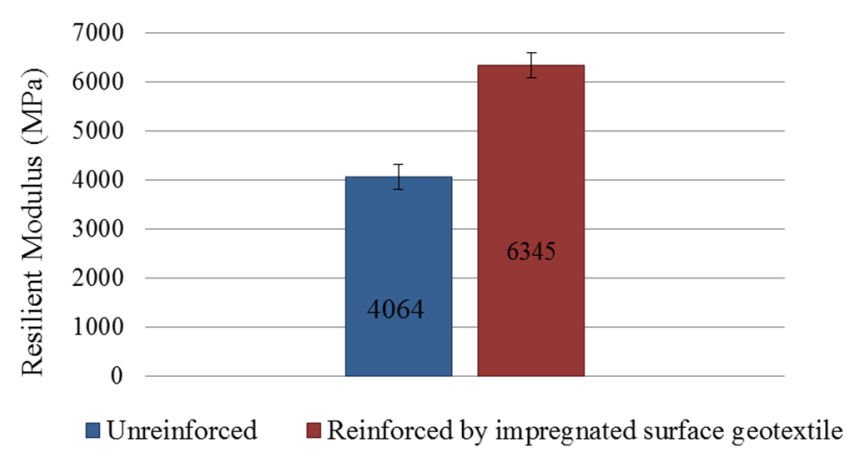

(b)

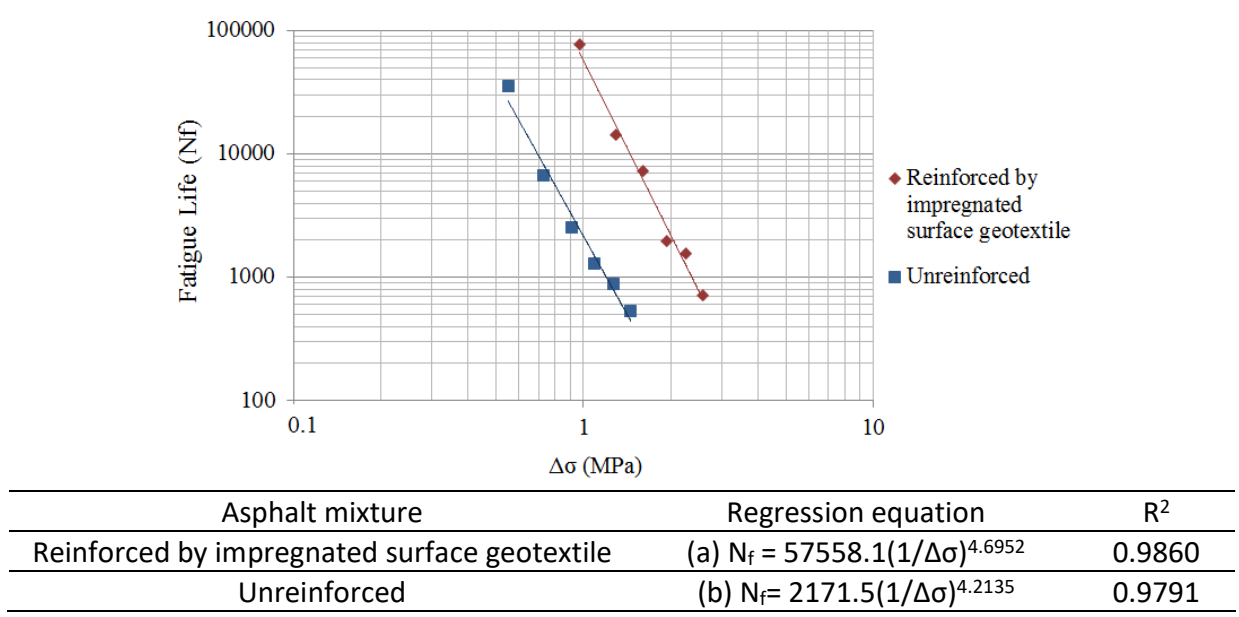

(c)

Figure 3. Average values obtained for specimens of composite asphalt mixtures with and without impregnated geotextile reinforcement [(a) TS and (b) RM]; Fatigue life curves of the analyzed composite asphalt mixtures and linear regression equations derived from these curves (c)

Research developed by Gonzalez-Torre et al. (2015) concluded that reinforced surface course with impregnated geotextiles showed better behavior in relation to the inhibition of the cracking propagation mechanism. According to these authors, the impregnated geotextiles produced an adherence/bond between the upper and lower layers of the surface course, contributing to a satisfactory performance as anti-reflective cracking system due to the greater elastic stiffness of the system. The findings of these authors corroborate the thesis that the greater elastic stiffness of the reinforced system, translated by the higher RM values (Figure 3b), resulted from the impregnation of geotextile's surface, providing the adequate adherence of the geosynthetic element to the asphalt layers and, consequently, better resilient response to the dynamic loading characteristic of the RM test. 
It is noteworthy that the $\mathrm{R}^{2}$ values are close to the unit (Figure $3 \mathrm{c}$ ), showing the statistical ability of the adopted mathematical model to explain the experimental data resulting from the laboratory tests.

For the stresses difference range $(\Delta \sigma)$ considered in the experimental program (Figure 3c), it is found that reinforced composite asphalt mixtures by impregnated surface geotextile tend to have a better structural performance regarding fatigue susceptibility, which also highlights the effect of geotextile impregnation on the mobilization of this improvement, in line with the arguments previously presented for TS and RM mechanical properties.

Considering the results of the fatigue life test together with the other mechanical laboratory tests included in the research, the unequivocal capacity of impregnated geotextile reinforcement can be seen in increasing properties the tensile strength, elastic stiffness and fatigue life of the investigated asphalt mixture. It should be noted, however, that such analyzes are restricted to asphalt mixture as an isolated structural element and should serve as a basis for structural analysis of asphalt pavement as a whole, while multilayer system for the different pre-defined loading scenarios.

\subsection{Structural analysis of asphalt pavement}

\subsubsection{Initial considerations}

For all structural analysis represented in the following items, it was considered the $80 \mathrm{kN}$ loading by axis condition and $563 \mathrm{kPa}$ filling pressure level of tires. Similar sections were generated for the other loading and tire pressure level conditions foreseen in this research.

\subsubsection{Horizontal stresses}

Figure 4 presents the horizontal stresses $\left(\sigma_{\mathrm{h}}\right)$ acting on the asphalt pavement structure, whose surface course was reinforced with impregnated surface geotextile (Figure $4 \mathrm{a}$ ) and unreinforced (Figure 4b).

Figure 4 shows the maximum horizontal tensile stresses $\left(\sigma_{\mathrm{ht}}\right)$ obtained at the lower edge of the reinforced surface course by geotextile and the unreinforced surface course $(\mathrm{Z}=-100 \mathrm{~mm}$, binder course), as a function of loading variation and filling pressure levels of tires at the analysis points proposed for this research. The TS/ $\sigma_{h t}$ ratios are also presented, which correspond to safety coefficient (SC) to static tensile failure.

As predicted, the maximum horizontal tensile stresses ( $\sigma_{\mathrm{ht}}$ ) for both reinforced and unreinforced scenarios were higher as loading and tire pressure increase. The highest magnitudes of $\sigma_{\text {ht }}$ were observed at the points located under the wheels.

Maximum horizontal tensile stresses corresponding to reinforced asphalt mixtures were found to be higher than the TS's average (1.11 MPa) at the $118 \mathrm{kN}$ loading with $703 \mathrm{kPa}$ filling pressure level of the tires. Thus, for this particular scenario, the SC value was lower than the unit, suggesting a greater susceptibility of the surface course to the risk of static tensile failure.

It is noteworthy that this $118 \mathrm{kN}$ loading scenario was analyzed with the objective of investigating possible damage observed on highways due to excessive traffic load and volume. According to Airey (2004) and Chantachot et al. (2016), damage to asphalt pavements caused by the lack of weight control of heavy vehicles leads to pavement inoperability. For these authors, an effective method for improving asphalt pavement performance is to reinforce it with geosynthetics. Therefore, improvements to the surface course itself or the overall pavement structure or both are needed so that the service life of the road can be effectively extended. 
The insertion of the impregnated geotextile in the surface course caused a change in the adherence condition between the layers. It is suggested that the transversal reaction module, representative of this adherence at the interface, is underestimated in the reinforced scenario. It is known that decreases in this module indicate an increase in tensile strain. Torquato and Silva (2018) found that the adherence between the surface course and the granular base comes from two sources, namely: impregnation binder and friction between the aggregates of both layers. Therefore, the transversal reaction module would be measured by both plots, making it possible to consider the interface in a more realistic way in mechanistic-empirical methods. It is believed that the parameter related to the friction between the reinforcement and the asphalt layers was not considered in the adherence gain, that is, the only source of adherence in the layers interface was provided by the portion related to the impregnation of the geotextile of reinforcement.

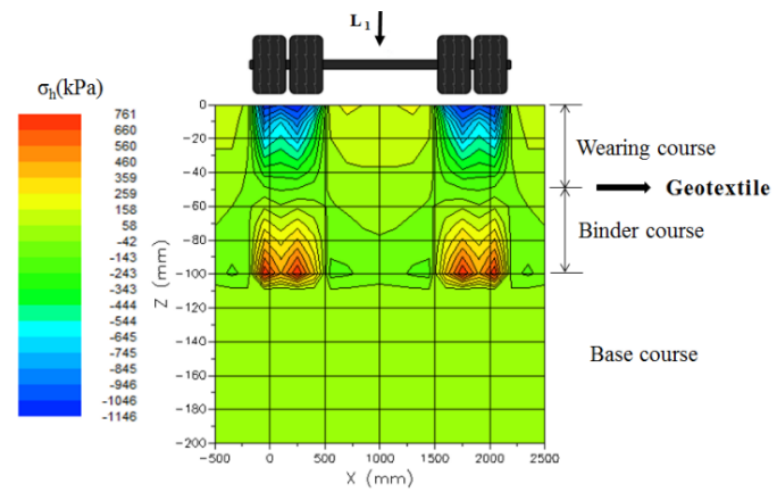

(a)

\begin{tabular}{cccc}
\hline \multicolumn{5}{c}{ Analysis Parameters } \\
\hline Points & $\begin{array}{c}\text { Point coordinates } \\
(\mathrm{X} ; \mathrm{Y} ; \mathrm{Z})\end{array}$ & Laxis $(\mathrm{kN})$ & $\mathrm{P}_{\text {tires }}(\mathrm{kPa})$ \\
\hline 1 & $(0 ; 0 ;-100)$ & & \\
2 & $(150 ; 0 ;-100)$ & 80 & 563 \\
3 & $(300 ; 0 ;-100)$ & & \\
\hline 1 & $(0 ; 0 ;-100)$ & & \\
2 & $(150 ; 0 ;-100)$ & 98 & \\
3 & $(300 ; 0 ;-100)$ & & \\
\hline 1 & $(0 ; 0 ;-100)$ & & \\
2 & $(150 ; 0 ;-100)$ & 118 & 703 \\
3 & $(300 ; 0 ;-100)$ & &
\end{tabular}
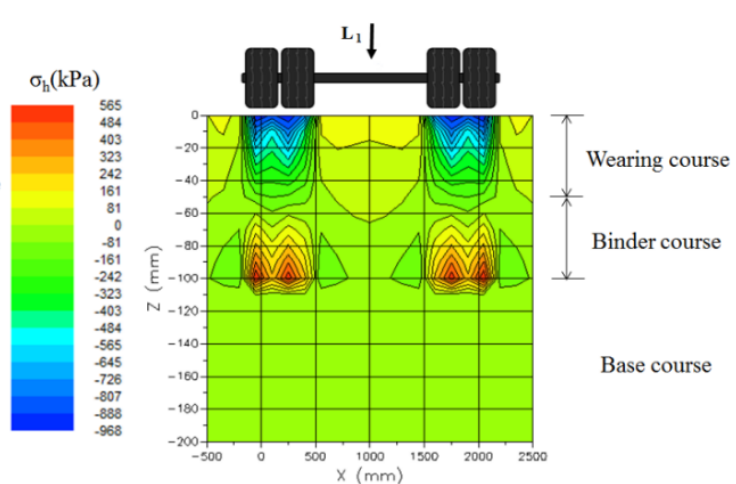

(b)

Figure 4. Maximum horizontal tensile stresses ( $\sigma \mathrm{ht}$ ) in the asphalt pavement structure analyzed in the me-PADS: (a) reinforced surface course and (b) unreinforced surface course

Despite the TS and RM increments provided by reinforcement (Figures 3a and 3b), it is known that more rigid structural layers, which have higher RM magnitudes, tend to concentrate/absorb more intensely the stresses internally generated by external loading, restricting their redistribution among the other structural layers of the pavement. Therefore, although the TS was higher for the reinforced system, the maximum horizontal tensile stresses acting on the lower edge of the binder course were also higher for this system, due to the proportionally larger increase of its rigidity.

The safety coefficient to static tensile failure (SC), by translating the relationship between the maximum horizontal tensile stress (provided by structural analysis) and static TS (provided by laboratory testing), reflects the proportionally greater increase in $\sigma_{\text {ht }}$ in relation to the TS for 
the reinforced system. This type of analysis, based on static bearing property (TS), thus runs counter to the benefits generated by geosynthetic reinforcement.

There is a consensus in the specialized technical literature that static properties, such as TS, do not translate the mobilized strength by the material under dynamic loading condition, that is, under the simulation of vehicle traffic action (Tayfur et al., 2007; Wang et al., 2017). According to Liu et al. (2019), dynamic test methods are recommended for characterization of structural materials for pavement analysis as they best reproduce the stress state in the pavement under moving vehicle load and are therefore more consistent with the traffic reality.

In view of several studies concerning the adherence between layers under different pressures and load conditions, Raab and Partl (2009) found that the influence of traffic loads improves the connection between layers by $40 \%$ to $57 \%$ after 10 years of service life, due to recompacting the pavement. In this perspective, it is believed that under the condition of static loading that characterizes the test of tensile strength by diametral compression, despite the existence of mobilization of the geosynthetic reinforcement, evidenced by the increase in TS compared to the unreinforced asphalt mixture, the static character of loading does not favor the aforementioned mechanism of progressive adherence (connection by recompaction) promoted by the dynamic loading representative of the traffic, implying gains in tensile strength lower than those that could be obtained under this condition of loading, underestimating, therefore, the potential for improvement the mechanical performance provided by the reinforcement.

\subsubsection{Fatigue life analysis}

Regarding the fatigue life analysis of the proposed surface course (reinforced and unreinforced), it was necessary to obtain the stresses difference $(\Delta \sigma)$ at the lower edge of the binder course, given by the difference between the previously obtained maximum horizontal tensile stresses $\left(\sigma_{\mathrm{ht}}\right)$, presented in Figure 4, and the vertical compression stresses $\left(\sigma_{\mathrm{vc}}\right)$. Figure 5 shows the vertical stresses $\left(\sigma_{\mathrm{v}}\right)$ acting on the adopted reinforced and unreinforced asphalt pavement (Figure $5 \mathrm{a}$ and Figure 5b, respectively).

With the respective fatigue equations obtained for the reinforced and unreinforced composite asphalt mixtures (Figure 3c), the $\Delta \sigma$ values were used to determine the fatigue life for both reinforcement scenarios ( $\mathrm{N}_{\text {flabRe }}$ and NflabUnre), at the laboratory scale. Figure 5 shows the vertical compression stresses $\left(\sigma_{\mathrm{vc}}\right)$ obtained at the respective lower edges of the reinforced and unreinforced surface course $(Z=-100 \mathrm{~mm}$, binder course), as a function of loading and filling pressure levels of the tires variation. The values of stress difference $(\Delta \sigma)$ and number of load repetions to failure $\left(\mathrm{N}_{\text {flab}}\right)$ for both surface course are also presented. Figure 5 shows the respective $\mathrm{N}_{\text {flab }}$ ratios of reinforced and unreinforced surface course ( $\mathrm{R}_{\mathrm{f}}$ or fatigue ratio).

In this context, the values obtained for $\mathrm{R}_{\mathrm{f}}$ indicate the tendency for structural performance improvement of pavements consisting of reinforced surface course by impregnated surface geotextile compared to the unreinforced ones. Predictably, as the loading magnitude increases the fatigue ratio has decreased due to the greater magnitude of the stresses difference in the lower fiber of the binder course.

The analysis based on the dynamically determined structural response parameter $\left(\mathrm{N}_{\mathrm{f}}\right.$ or fatigue life) shows, for the particularities of this research, a structural superiority of the reinforced system by impregnated surface geotextile compared to the unreinforced one. Regardless of the adopted loading levels and filling pressure levels of the tires, higher $\mathrm{N}_{\text {flab }}$ values were found for the scenario in which the system was reinforced. Rescuing the previous discussion 
that emphasizes that structural safety analyzes are better translated based on dynamic properties, such as $\mathrm{N}_{\mathrm{f}}$, can be concluded that this analysis highlights the potential for improving the structural performance of asphalt pavement in fatigue due to the insertion of said reinforcement. This enhancement allows the pavement to withstand a greater number of load repetitions without the occurrence of structural damage by fatigue, extending the service life of the adopted asphalt pavement.

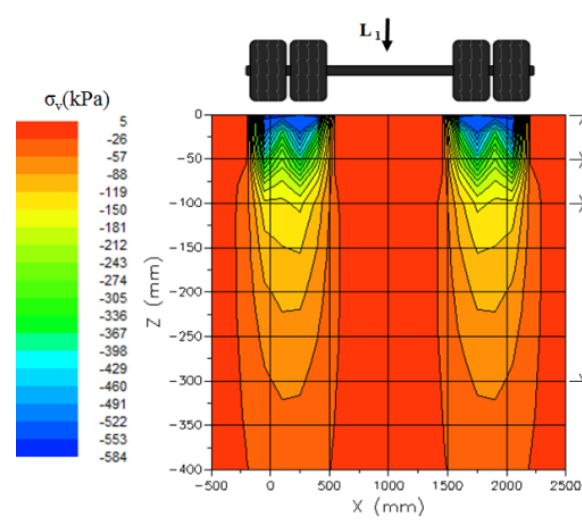

(a)

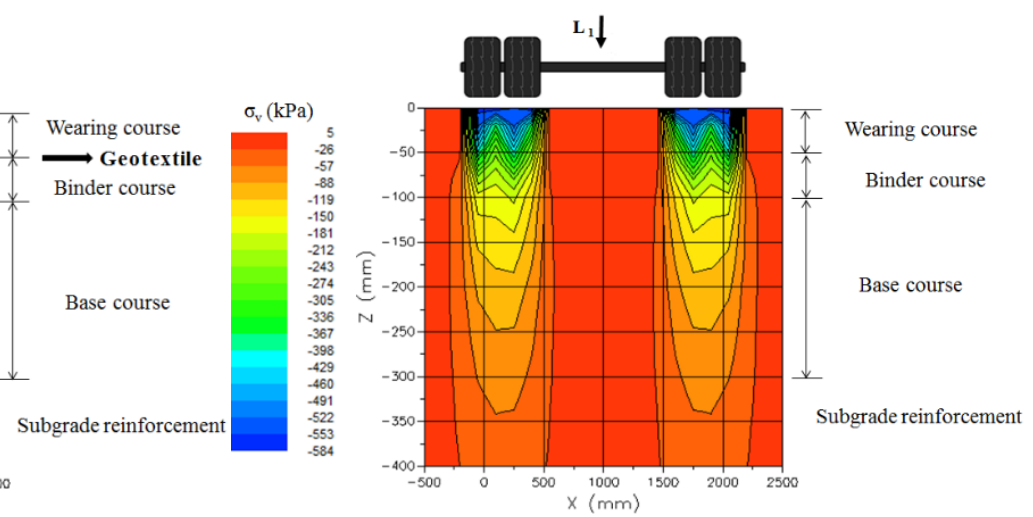

(b)

\begin{tabular}{|c|c|c|c|c|c|c|c|c|c|c|}
\hline \multicolumn{4}{|c|}{ Analysis parameters } & \multicolumn{3}{|c|}{ Reinforced } & \multicolumn{3}{|c|}{ Unreinforced } & \multirow[b]{2}{*}{$\begin{array}{c}R_{\mathrm{f}}=\mathrm{N}_{\text {flabRe }} / \\
\mathrm{N}_{\text {flabUnre }}\end{array}$} \\
\hline Points & $\begin{array}{c}\text { Point } \\
\text { coordinates } \\
(\mathrm{X} Y \mathrm{Y} ; \mathrm{Z})\end{array}$ & $\begin{array}{l}\mathrm{L}_{\text {axis }} \\
(\mathrm{kN})\end{array}$ & $\begin{array}{l}P_{\text {tires }} \\
(\mathrm{kPa})\end{array}$ & $\begin{array}{c}\sigma_{\mathrm{vc}} \\
(\mathrm{MPa})\end{array}$ & $\begin{array}{c}\Delta \sigma= \\
\left(\sigma_{\mathrm{ht}}-\sigma_{\mathrm{vc}}\right)\end{array}$ & $\mathrm{N}_{\text {flabRe }}$ & $\begin{array}{c}\sigma_{\mathrm{vc}} \\
(\mathrm{MPa})\end{array}$ & $\begin{array}{c}\Delta \sigma= \\
\left(\sigma_{\mathrm{ht}}-\sigma_{\mathrm{vc}}\right)\end{array}$ & $N_{\text {flabUnre }}$ & \\
\hline 1 & $(0 ; 0 ;-100)$ & & & -0.159 & 1.032 & $4.96 \times 10^{4}$ & -0.191 & 0.852 & $4.26 \times 10^{3}$ & 11.64 \\
\hline 2 & $(150 ; 0 ;-100)$ & 80 & 563 & -0.133 & 0.396 & $4.46 \times 10^{6}$ & -0.148 & 0.234 & $9.87 \times 10^{5}$ & 4.51 \\
\hline 3 & $(300 ; 0 ;-100)$ & & & -0.159 & 1.028 & $5.06 \times 10^{4}$ & -0.191 & 0.851 & $4.28 \times 10^{3}$ & 11.80 \\
\hline 1 & $(0 ; 0 ;-100)$ & & & -0.190 & 1.209 & $2.36 \times 10^{4}$ & -0.227 & 0.993 & $2.23 \times 10^{3}$ & 10.56 \\
\hline 2 & $(150 ; 0 ;-100)$ & 98 & 633 & -0.163 & 0.513 & $1.32 \times 10^{6}$ & -0.182 & 0.314 & $2.86 \times 10^{5}$ & 4.62 \\
\hline 3 & $(300 ; 0 ;-100)$ & & & -0.190 & 1.205 & $2.40 \times 10^{4}$ & -0.227 & 0.992 & $2.24 \times 10^{3}$ & 10.68 \\
\hline 1 & $(0 ; 0 ;-100)$ & & & -0.223 & 1.394 & $1.20 \times 10^{4}$ & -0.266 & 1.138 & $1.25 \times 10^{3}$ & 9.61 \\
\hline 2 & $(150 ; 0 ;-100)$ & 118 & 703 & -0.197 & 0.653 & $4.26 \times 10^{5}$ & -0.221 & 0.412 & $9.10 \times 10^{4}$ & 4.67 \\
\hline 3 & $(300 ; 0 ;-100)$ & & & -0.223 & 1.390 & $1.23 \times 10^{4}$ & -0.266 & 1.137 & $1.26 \times 10^{3}$ & 9.70 \\
\hline
\end{tabular}

Note: (-) lower fiber compression and (+) lower fiber tensile.

Figure 5. Vertical compression stresses ( $\sigma \mathrm{vc}$ ) in the asphalt pavement structure analyzed in the me-PADS: (a) reinforced surface course and (b) unreinforced surface course.

\section{CONCLUSIONS}

Based on the results obtained in this research, the following conclusions can be obtained:

- The insertion of impregnated surface geotextile reinforcement to the investigated asphalt mixture provided increases in static tensile strength and elastic stiffness, as well as reducing the risk of fatigue cracking;

- Impregnation on the upper side of the geotextile promoted an adequate adherence/contact condition among the asphalt layers and the reinforcement, reducing the exposure of the reinforced surface course to structural pathologies arising from detachment or discontinuity in the geotextile-asphalt layers interface;

- The mechanistic-empirical approach allowed the analysis of the structural responses of the pavements as a multilayer system, being more representative of the asphalt pavement as a whole, highlighting the potential for improved structural performance of reinforced asphalt pavement; 
- It is believed that the static properties may have obscured the improvements generated by geosynthetic reinforcement, since these properties do not capture the stress state of the pavement under moving vehicle load, which make those properties not consistent with the traffic reality.

\section{ACKNOWLEDGEMENTS}

The authors thank the Higher Education Personnel Improvement Coordination (CAPES) for their financial support.

\section{REFERENCES}

Airey, G. D. (2004) Fundamental binder and practical mixture evaluation of polymer modified bituminous materials. International Journal of Pavement Engineering, v. 5, n. 3, p. 137-151. DOI: 10.1080/10298430412331314146.

Aldea, C. M. and J. R. Darling (2004) Effect of coating on fiberglass geogrid performance. Fifth International RILEM Conference on Reflective Cracking in Pavements, France, n. 37, p. 81-88.

Alhasan, A.; A. Ali; D. Offenbacker; O. Smadi and C. Lewis-Beck (2018) Incorporating spatial variability of pavement foundation layers stiffness in reliability-based mechanistic-empirical pavement performance prediction. Transportation Geotechnics, v. 17, p. 1-13. DOI:10.1016/J.TRGEO.2018.08.001.

ARA, I. and ERES Division (2004) Guide for Mechanistic-Empirical Design of New and Rehabilitated Pavement Structures. National Cooperative Highway Research Program, NCHRP Project, Canada, v. 1-37A, 219p.

Brown, S. F.; N. H. Thom and P. J. Sanders (2001) A study of grid reinforced asphalt to combat reflection cracking (with discussion). Journal of the Association of Asphalt Paving Technologists, v. 70, p. 543-571.

Caltabiano, M. A. and J. M. Brunton (1991) Reflection cracking in asphalt overlays. Association of Asphalt Paving Technologists Technical Sessions, USA, v. 60, p. 310-320.

Carmo, C. A. T. (1998) A avaliação do módulo de resiliência através de ensaios triaxiais dinâmicos de dois solos compactados e a sua estimativa a partir de ensaios rotineiros, dissertação (Mestrado em Engenharia de Transportes), Escola de Engenharia de São Carlos da Universidade de São Paulo, São Carlos, 131p.

Chantachot, T.; W. Kongkitkul; S. Youwai and P. Jongpradist (2016) Behaviours of geosynthetic-reinforced asphalt pavements investigated by laboratory physical model tests on a pavement structure. Transportation Geotechnics, v. 8, p. 103-118. DOI:10.1016/J.TRGE0.2016.03.004.

DNER (1995) ME 043 - Misturas betuminosas a quente - ensaio Marshall. Departamento Nacional de Estradas de Rodagem, Rio de Janeiro, 11p.

DNIT (2006a) ES 031 - Pavimentos Flexíveis - Concreto Asfáltico. Especificação de Serviço. Departamento Nacional de Infraestrutura e Transportes. Rio de Janeiro, $14 \mathrm{p}$.

DNIT (2006b) EM 095 - Cimentos asfálticos de petróleo. Especificação de material. Departamento Nacional de Infraestrutura e Transportes. Rio de Janeiro, $6 \mathrm{p}$.

DNIT (2012) ES 145 - Pavimentação - Pintura de ligação com ligante asfáltico. Especificação de serviço. Departamento Nacional de Infraestrutura e Transportes. Rio de Janeiro, $7 \mathrm{p}$.

DNIT (2018a) ME 135 - Pavimentação asfáltica - Misturas asfálticas - Determinação do módulo de resiliência. Método de ensaio. Departamento Nacional de Infraestrutura e Transportes. Rio de Janeiro, 6p.

DNIT (2018b) ME 136 - Pavimentação asfáltica - Misturas asfálticas - Determinação da resistência à tração por compressão diametral. Método de Ensaio. Departamento Nacional de Infraestrutura e Transportes. Rio de Janeiro, 6 p.

DNIT (2018c) ME 183 - Pavimentação asfáltica - Ensaio de Fadiga por compressão diametral à tensão controlada. Método de ensaio. Departamento Nacional de Infraestrutura e Transportes. Rio de Janeiro, 15p.

Ferrotti, G.; F. Canestrari; E. Pasquini and A. Virgili (2012) Experimental evaluation of the influence of surface coating on fiberglass geogrid performance in asphalt pavements. Geotextiles and Geomembranes, v. 34, p. 11-18. DOI:10.1016/J.GEOTEXMEM.2012.02.011.

Gonzalez-Torre, I.; M. A. Calzada-Perez; A. Vega-Zamanillo and D. Castro-Fresno (2015) Experimental study of the behaviour of different geosynthetics as anti-reflective cracking systems using a combined-load fatigue test. Geotextiles and Geomembranes, v. 43, n. 4, p. 345-350. DOI: 10.1016/J.GEOTEXMEM.2015.04.001.

Khodaii, A.; S. Fallah and F. M. Nejad (2009) Effects of geosynthetics on reduction of reflection cracking in asphalt overlays. Geotextiles and Geomembranes, v. 27, n. 1, p. 1-8. DOI: 10.1016/J.GEOTEXMEM.2008.05.007.

Kumar, V. V. and S. Saride (2018) Evaluation of cracking resistance potential of geosynthetic reinforced asphalt overlays using direct tensile strength test. Construction and Building Materials, v. 162, p. 37-47. DOI: 10.1016/J.CONBUILDMAT.2017.11.158.

Li, P.; J. Liu and S. Zhao (2016) Performance of multiaxial paving interlayer-reinforced asphalt pavement. Journal of Materials in Civil Engineering, v. 28, n. 7. DOI:10.1061/(ASCE)MT.1943-5533.0001543.

Liu, X.; X. Zhang; H. Wang and B. Jiang (2019) Laboratory testing and analysis of dynamic and static resilient modulus of subgrade soil under various influencing factors. Construction and Building Materials, v. 195, p. 178-186. D0I:10.1016/J.CONBUILDMAT.2018.11.061.

Ponte, R. S.; V. T. F. C. Branco; A. S. Holanda e J. B. Soares (2014) Avaliação de diferentes metodologias para obtenção do Módulo de Resiliência de misturas asfálticas. Revista Transportes, v. 22, n. 2, p. 85-94. DOI: 14295/transportes.v22i2.792. 
Prieto, J. N.; J. Gallego and I. Perez (2007) Application of the wheel reflective cracking test for assessing geosynthetics in antireflection pavement cracking systems. Geosynthetics International, v. 14, n. 5, p. 287-297. DOI: 10.1680/gein.2007.14.5.287.

Raab, C. and M. N. Partl (2009) Interlayer bonding of binder, base and subbase layers of asphalt pavements: long-term performance. Construction and Building Materials, v. 23, n. 8, p. 2926-2931. DOI: 10.1016/j.conbuildmat.2009.02.025.

Rezende, J. P.; H. N. Pitanga; T. O. Silva; N. F. Silva e G. S. Pereira (2018) Análise comparativa dos efeitos da impregnação do geotêxtil na resposta mecânica de misturas a quente compostas. Anais do XXXII Congresso de Pesquisa e Ensino em Transportes (ANPET), Gramado - RS, p. 1608-1619.

Saride, S. and V. V. Kumar (2017) Influence of geosynthetic-interlayers on the performance of asphalt overlays on pre-cracked pavements. Geotextiles and Geomembranes, v. 45, n. 3, p. 184-196. DOI: 10.1016/J.GEOTEXMEM.2017.01.010.

Sudarsanan, N.; R. Karpurapu and V. Amrithalingam (2018) An investigation on the interface bond strength of geosyntheticreinforced asphalt concrete using Leutner shear test. Construction and Building Materials, v. 186, p. 423-437. DOI:10.1016/J.CONBUILDMAT.2018.07.010.

Tang, X.; S. M. Stoffels and A. M. Palomino (2016) Mechanistic-empirical approach to characterizing permanent deformation of reinforced soft soil subgrade. Geotextiles and Geomembranes, v. 44, n. 3, p. 429-441. DOI: 10.1016/J.GEOTEXMEM.2015.06.004.

Tayfur, S.; H. Ozen and A. Aksoy (2007) Investigation of rutting performance of asphalt mixtures containing polymer modifiers. Construction and Building Materials, v. 21, n. 2, p. 328-337. DOI: 10.1016/J.CONBUILDMAT.2005.08.014.

Torquato e Silva, S. A.; J. B. Soares e S. H. A. Barroso (2018) Modelagem constitutiva e caracterização empírica da interface revestimento asfáltico - base granular. Revista Transportes, v. 26, n. 2, p. 180-190. DOI: 10.14295/transportes.v25i1.1661.

Virgili, A.; F. Canestrari; A. Grilli and F. A. Santagata (2009) Repeated load test on bituminous systems reinforced by geosynthetics. Geotextiles and Geomembranes, v. 27, n. 3, p. 187-195. DOI: 10.1016/J.GEOTEXMEM.2008.11.004.

Vismara, S.; A. A. A. Molenaar; M. Crispino and M. R. Poot (2012) Toward a better understanding of benefits of geosynthetics embedded in asphalt pavements. Transportation Research Record, v. 2310, n. 1, p. 72-80. DOI: 10.3141/2310-08.

Wang, L.; Y. Hou; L. Zhang and G. Liu (2017) A combined static-and-dynamics mechanics analysis on the bridge deck pavement. Journal of Cleaner Production, v. 166, p. 209-220. DOI: 10.1016/J.JCLEPRO.2017.08.034.

Zamora-Barraza, D.; M. A. Calzada-Pérez; D. Castro-Fresno and A. Vega-Zamanillo (2011) Evaluation of anti-reflective cracking systems using geosynthetics in the interlayer zone. Geotextiles and Geomembranes, v. 29, n. 2, p. 130-136. DOI:10.1016/J.GEOTEXMEM.2010.10.005.

Zamora-Barraza, D.; M. Calzada-Peréz; D. Castro-Fresno and A. Vega-Zamanillo (2010) New procedure for measuring adherence between a geosynthetic material and a bituminous mixture. Geotextiles and Geomembranes, v. 28, n. 5, p. $483-489$. DOI: 10.1016/J.GEOTEXMEM.2009.12.010. 